\title{
Psychological Expertise in Cases of Interparental Conflict: Recommendations for Practice
}

\author{
Ana Isabel Sani ${ }^{1}$ \\ Faculdade de Ciências Humanas e Sociais, Universidade Fernando Pessoa, Porto, Portugal
}

\begin{abstract}
Forensic psychological assessment often comprises technical guidance in courts, especially in more complex matters in different areas to which psychology can provide significant explanatory support. Psychological examination in court proceedings involving children in difficult situations of parenting conflicts requires expert technicians to have specific knowledge and competence to efficiently respond to judicial demands, taking into account the best interest of the child. This article reviews some of the key aspects to be analyzed, proposing a reflection on the areas and elements that should be considered and/or prioritized in such assessments and that raise a series of subjectivities and explorations that go beyond the domain of discourse and facts. The family dynamics, relationships and bonds between family members, expressed preferences and dislikes are dimensions that must to be analyzed for which there simple and complex underlying processes. The forensic psychological assessment should bring together the comprehensive analysis of all these aspects, combining theoretical knowledge with technical and scientific competence for the best interests of the child.
\end{abstract}

Keywords: Psychological assessment, courts, interparental conflicts, expertise, child.

\section{Perícias Psicológicas em Casos de Conflito Interparental: Recomendações para a Prática}

\section{Resumo}

A avaliação psicológica forense traduz-se frequentemente num trabalho de assessoria técnica aos tribunais, em matérias de particular complexidade e em domínios diversos, às quais a psicologia poderá dar especial contributo explicativo. A realização de perícias psicológicas em processos judiciais que envolvem crianças em situações difíceis de conflitos interparentais exige da parte dos técnicos conhecimentos e competências especiais, de modo a melhor responder à solicitação judiciária considerando o superior interesse da criança. Este artigo foca alguns dos principais aspectos que devem ser analisados, encetando uma reflexão sobre as áreas e os elementos que devem ser atendidos e/ou privilegiados nessa avaliação e que nos remetem, entre outros, para uma série de subjetividades e explorações que ultrapassam o domínio do discurso e dos fatos. As dinâmicas familiares, as relações e vinculações entre os membros da família, os afetos e desafetos exprimidos são dimensões que devem ser analisadas, para os quais existem subjacentes processos simples e complexos. A perícia psicológica forense deve reunir a

\footnotetext{
Mailing address: Universidade Fernando Pessoa, Faculdade de Ciências Humanas e Sociais, Praça 9 de abril, 349, Porto, Portugal 4249-004. Phone. + 351225071300 | ext. 2305; Fax: +351 22 5508269; E-mail: anasani@, ufp.edu.pt;

This work was funded by National Funds through FCT (Foundation for Science and Technology) and cofinanced by the European Regional Development Fund (ERDF) through the COMPETE 2020 - Operational Programme for Competitiveness and Internationalisation (POCI) in the CIEC (Research Centre on Child Studies at the University of Minho) with POCI-01-0145-FEDER-007562 reference.
} 
análise compreensiva de todos estes aspectos, combinando o conhecimento teórico com a competência técnica e científica para o melhor interesse da criança.

Palavras-chave: Avaliação psicológica, tribunais, conflitos interparentais, perícia, criança.

\section{Pericia Psicológica en Casos de Conflicto entre los Padres: Recomendaciones para la Práctica}

\section{Resumen}

La evaluación psicológica forense consiste frecuentemente en una actividad de asesoría técnica a los tribunales en materias de especial complejidad y en diversos ámbitos en que la psicología puede realizar aportaciones explicativas del caso en análisis. La realización de pericias psicológicas en procesos judiciales que implican los niños ante un conflicto entre padres requiere, por parte de los técnicos, conocimientos y habilidades especiales para que la decisión judicial tenga en consideración el interés superior del menor. Este artículo se centra en algunos de los aspectos que deben ser analizados en la evaluación psicológica, haciéndonos una reflexión sobre los elementos que debe recoger esa evaluación y que nos conducen a abordar una serie de subjetividades y exploraciones que van más allá del análisis del discurso y de los hechos. La dinámica familiar, las relaciones y vínculos entre los miembros de la familia, los afectos y desafectos expresados son dimensiones que deberán ser examinadas, para los cuales existen subyacentes procesos simples y complejos. La pericia psicológica forense debe cumplir con el análisis exhaustivo de todos estos aspectos, combinando los conocimientos teóricos con la experiencia técnica y científica para el mejor interés del niño.

Palabras clave: Evaluación psicológica, tribunales, conflictos entre los padres, pericia, niños.

The family plays an important role in the socialization of the child. Parents and caretakers are the main role models who shape the attitudes and behaviors of the child, which, later in life, may be reflected in the child's relationships (Bevan \& Higgins, 2002). Therefore, it is crucial for the child's development to occur in a balanced and harmonious context. However, if the relationships in the family are characterized by violent conflicts, then the child may learn and replicate, within the family and in other contexts, the aversive interactions has he/she witnessed (Laporte, Jiang, Pepler, \& Chamberland, 2011). When children witness violent behaviors, this experience reinforces the thought that living in conflict is legitimate and creates the conditions for the intergenerational transmission of violence (Almeida \& Sani, 2014; Black, Sussman, \& Unger, 2010; Marasca, Colossi, \& Falcke, 2013).

Scientific studies (e.g., Dankoski et al., 2006; Fergusson, Boden, \& Horwood, 2008; Laporte et al., 2011; Simon \& Furman, 2010) have identified a positive relationship between witnessing violent conflicts in the family and becoming involved in conflictual roman-tic relationships later in life. Thus, being exposed to violence between intimate partners, frequently the parents of the child (interparental violence), who may be in a marital or nonmarital relationship, is a relevant risk factor for the future replication of violent relational dynamics. In addition, these violent conflicts constitute a form of child victimization, which, although indirect, has serious implications in the balanced development of the child (Sani, 2011). The occurrence of violent conflicts within the family context, which is assumed to be a place of protection, and the fact that the individuals involved in this conflict are figures who are generally associated with attachment and affection also create the negative impact of this experience (Sani \& Almeida, 2011a).

Many violent family conflicts gain social visibility in the course of the follow-ups and assessments that are conducted within the scope of legal proceedings for the promotion and protec- 
tion of children and adolescents or in the context of contentious divorces, and in them, several of the above aspects, which are investigated in depth and emphasized to support court decisions, are recognized. Expert advice in the context of these legal proceedings can be a complex and demanding task for forensic psychologists (Machado \& Sani, 2014). These professionals should be well equipped with the knowledge and the technical and personal abilities to neutrally express the nuances, vicissitudes, and repercussions caused by interparental conflicts.

Therefore, based on a succinct literature review, we first address the understanding of the impact of exposing children to interparental conflicts to subsequently stress the crucial elements in conducting a forensic psychological assessment in the scope of legal proceedings involving children who have experienced the phenomenon.

\section{The Effects of Exposure to Interparental Conflicts on Children}

Some studies (e.g., English et al., 2009; Herrenhohl, Sousa, Tajima, Herrenhohl, \& Moylan, 2008) claim that children's exposure to violent interparental conflicts is more common than child maltreatment. Although the statistical extent of this phenomenon in Portugal is unknown, research data on the country (cf. Sani \& Almeida, 2011a) have stressed the effects that exposure to interparental violence may have on the child's overall adjustment. The consequences for children are, above all, psychological (Sani, 2011), although significant clinical problems have been identified at various levels (physiological, emotional, cognitive, and behavioral; Coutinho \& Sani, 2008; Patias, Bossi, \& Dell'Aglio, 2014; Sani, 2007).

Interparental conflicts may be expressed at different levels, having distinct implications for the exercise of the maternal and paternal roles. Consequently, the parental stress generated interferes in the child's adjustment. In a study conducted by Camisasca, Miragoli, and Di Blasio (2016) with 358 couples (fathers and mothers) of school-age children, the researchers demon- strate that high levels of interparental conflict negatively affect the child's adaptation. Nevertheless, even less explicit conflicts have a negative impact on the child. The fact that parents do not talk about their issues and do not admit the existence of an imminent conflict generates distress and confusion in the child because he/she is not able to understand relationships. It is not uncommon for a child to feel that he/she should resolve the situation; however, doing so is not always possible (Pryor \& Pattison, 2007). When children witness more intense conflicts, the perception of control is decreased, contributing to a negative impact of the experience (Sani, 2011). This impact could be particularly significant if the child lacks the personal resources to confront the situation (Hughes, Graham-Bermann, \& Gruber, 2001), which shows the importance of considering the mediating factors of the impact of this experience.

Indeed, the effect of exposure to interparental conflicts in children depends on several factors that can be related to aspects of the child or family or to the characteristics of the incidents experienced (Howell, 2011; Sani, 2006). Children's reactions to interparental conflicts vary considerably; some may exhibit trauma or severe levels of maladjustment (Costa \& Sani, 2007), whereas others may exhibit mild indicators or even the absence of symptoms. This variance demonstrates that to analyze the impact of exposure to interparental conflicts on the child's adjustment, it is necessary to consider the risk and protection factors associated with the child, parents, and environment (Hughes et al., 2001; Sani, 2006). Thus, examples of mediating factors include certain attributes of the child such as age, gender, cognitive style, intelligence level, personality, temperament, coping strategies, and the child's perception and interpretations, in addition to situational factors such as previous experience in handling stressful events (Cunningham \& Baker, 2004; Sani, 2006) and the success in confronting these situations. Other factors that are more related to the family also include examples such as socioeconomic status, the parents' child-rearing style (Sani, 2006), maternal sensitivity (Levendosky, 
Bogat, \& Huth-Bocks, 2011; Manning, Davies, \& Cicchetti, 2014), relationships with siblings (Dunn \& Davies, 2001), and the positive support provided by peers (Bowen, 2015). Contextual factors associated with the conflict (e.g., place of occurrence, frequency, intensity, duration, content, and conflict resolution) inform the child's construct of the severity of violent episodes (Sani, 2011) and thus equally mediate the impact of the experience.

Studies and clinical practice (Sani, 2004a) have confirmed the existence of a set of direct and indirect mechanisms (Hughes et al., 2001; Sani, 2006) that are able to influence the impact of the exposure to interparental conflicts on a child. Based on some of these studies, several explanatory theories have emerged to help understand how to process this impact (cf. Sani, 2004b). Therefore, considering the knowledge on this phenomenon, we must design scientific, technical, and ethical procedures that are adjustable to the demands of an expert assessment that addresses the needs of court decisions to serve the best interests of the child.

\section{Forensic Psychological Expertise in Cases of Interparental Conflicts}

As noted above, psychological expertise for the purposes of judicial decision making in cases involving children exposed to interparental conflicts requires that the expert be equipped with a set of theoretical and practical knowledge that allows him/her to organize the assessment procedures in a flexible and adjusted manner that is oriented toward the intended objectives (Sani \& Almeida, 2011b). Given the very frequently sensitive nature of these cases due to the presence of children who may be at risk, the assessment must consider the need for an intervention that protects the child.

Psychological examinations in cases of families who are engaged in substantial conflicts that involve adults and children are generally complex and difficult to perform (Machado \& Sani, 2014; Pereira \& Matos, 2011). These cases have been the object of frequent requests on behalf of judicial authorities for forensic psychological opinions. The complexity of the issues is generally related to the risk that adults and children may face in this context, in which violent behaviors may be exhibited, directly or indirectly experienced by a children, and naturally to parenting issues (Agulhas \& Anciães, 2014; Camisasca et al., 2016; Peixoto, Ribeiro, \& Manita, 2007; Pereira \& Matos, 2011). The risk also extends to the professionals involved because there is a high probability that their assessments will be contested and refuted through complaints and lawsuits (Machado \& Sani, 2014; Pereira \& Matos, 2011). Expert reports should be clear and credible and should respond to the objectives and questions formulated by the court.

Psychological examinations involve access to multiple sources (e.g., parents, child, and significant others), various methodologies (e.g., interviews, observation, the application of instruments, document analysis of the legal proceedings, and other relevant elements), and the analysis of the problem through its varied aspects (e.g., family dynamics, parenting, educational practices, and overall adjustment) for the report created to be able to support judicial decisions (Sani \& Almeida, 2011b). In regulatory proceedings of parental responsibilities, a common judicial request is the assessment of parental competencies to verify, especially in cases of intense litigation, which parent is more capable and competent to ensure the child's full development (Agulhas, 2014; Peixoto et al., 2007). Several factors are particularly relevant for the analysis, especially because there is no accepted universal model that defines "minimally adequate parenting" (Pereira \& Alarcão, 2010). In addition to the variety of theoretical models that address the concept of parenting, which focus on various aspects and propose multiple methods and evaluation parameters (Pereira \& Alarcão, 2010), the probabilistic nature of any assessment should take into account that the evaluation of parenting abilities will never be the only proof that is used in the decision (Peixoto et al., 2007). Indeed, when the assessment shows that both parents have adequate parenting abilities, other elements (e.g., the psychological assessment of the children, other reports) are used in the 
proceeding to support the conclusions reached through the evaluation of the parents (Machado \& Sani, 2014; Peixoto et al., 2007). Thus, without attempting to list all of the elements that are crucial to expert assessment in cases of interparental conflict, a systematization of the aspects that may serve as guidelines for forensic practice in this type of assessment is indispensable.

\section{Recommendations for an Assessment in Cases of Interparental Conflicts}

In any forensic psychological assessment, the opening of the case requires knowing who requested the examination, the questions formulated, and the particularities of the case. Thus, it is necessary to review the procedural data that aid the understanding of the case (Sani \& Almeida, 2011b). This review is a standard universal element in several evaluation protocols (e.g., Peixoto et al., 2007; Pereira \& Matos, 2011). In addition, informed consent and other authorizations are also obtained first and are crucial for the beginning of the other phases of the evaluation. In certain cases, the recording of interviews makes these requests key elements to the performance of the expert assessment.

The objective of the expert assessment is to understand the family dynamics and the psychological and psychosocial processes that are part of parenting and its subjective dimension through the use of several means and techniques, clinical data, and other elements that enable the child's and family's condition to be described (Peixoto et al., 2007). Thus, aspects such as the quality of the emotional bonds between the child and the parents, the parent's availability and capacity to foster the child's relationships with others, participation in the child's education, and the absence of violent situations are assessed (cf. Huss, 2011). Considering the theoretical aspects concerning the inexistence of a universal framework of reference on adequate parenting discussed above, in addition to cultural, contextual, and historical-temporal specificities (Fialho, 2012; Peixoto et al., 2007), the expert report should support the judicial decision, which should always serve the best interests of the child. Several organizations (e.g., the American Academy of Child and Adolescent Psychiatry, the American Psychological Association, and the Association of Family and Conciliation Courts) have proposed the standardization of assessment procedures, especially in regard to major areas (Agulhas, 2014) such as the quality of the parenting role (e.g., parental competencies, educational practices) or the relational dynamics (parents-children, siblingship, attitudes of cooperation, and communication between parents).

The quality of parenting is one of the main aspects to be assessed. The dissolution of the conjugal relationship does not invalidate the fact that parents, in particularly important matters (e.g., school choice, surgeries, work, and religious orientation), should assume equal shared parental responsibilities (cf. Fialho, 2012). In this case, it is necessary to assess whether this parental coordination is possible and whether each parent's parenting style is functional or, conversely, whether it is not feasible and harms the child's interests and right to protection and full development. Regarding the latter, there is room for the exclusive exercise of parental responsibilities, for instance, when it can be proven that violent interparental conflicts exist (Agulhas \& Anciães, 2014).

The family dynamics is also a crucial element of the expert assessment. The existence of violent interparental conflicts denies the possibility of safe and balanced child development in the family, a reason to entirely disregard the shared living arrangement of parents who are involved in abusive dynamics. Thus, the eventual definition of parental responsibilities and/or sole custody will naturally have implications for the establishment of the parent-child relationship and its quality. Decreasing child-parent contact is not beneficial to their bonding, which is not what the court order intends. However, the scientific literature indicates that even living more separately from one parent, the child can develop safe ties with both parents, which may lead to a less intense and negative experience of interparental conflicts on the part of the child (Cox, Paley, \& Harter, 2001). This outcome is only possible if the parents, although still engaging in marital conflicts, are able to separate 
these conflicts from the parental responsibilities that each should assume.

When the court decisions make it possible to end the child's contact with interparental conflicts and if, during the time allocated for the child to spend with the parents, some conditions that favor the establishment of ties are created (and not their destruction), then this element should be emphasized in the assessment. However, if the assessment reveals a real negative experience (Agulhas \& Anciães, 2014), such as direct or indirect experience of violence in the family, then it is important to assess whether the rejection manifested comes from the child (e.g., because he/she was a victim of maltreatment) or is induced by others. There may be complex psychological processes that demand a comprehensive assessment to avoid conventional interpretations. For example, a situation in which the child rejects one of the parents may arise due to several factors: (a) it may result from the efforts of one parent to negatively affect the relationship of the child with the rejected parent (parental alienation attempt ${ }^{2}$ ); (b) it may arise when it becomes unbearable for the child to witness constant passivity from one of the parents in the interparental conflict; (c) the child commits a backlash against the abusive behavior of one of the parents; (d) it may be a style that is adopted by the child as a direct effect of the exposure to interparental conflicts or $\mathrm{v}$ ) be the result of any other process that requires further psychological evaluation.

It is important for the expert ${ }^{3}$ to perform a dynamic evaluation of the family and observe

This is a type of child maltreatment with a negative impact on various dimensions of the child's life (Machado \& Sani, 2015), and the early identification of these cases is crucial. The intervention, which is dependent on the levels of alienation present, should favor a multidisciplinary approach that is focused on the child's needs and the parental capacities to meet them (Molinari \& Sani, 2015a, 2015b; Molinari \& Trindade, 2014).

3 The expert's duties are defined in article 153 of the Portuguese Code of Criminal Procedure. The technical assistant, as described in the Brazilian legislation, does not exist in Portugal. In Portugal, the law (as a rule) excludes a regimen of which processes may be operating and who mobilizes them. Here, the assessment of the child is a key element, taking into account aspects such as the discourse (e.g., justifications, contradictions, and pauses) or posture shown. Thus, it is important to observe the verbal and non-verbal elements and, above all, to evaluate how all relevant aspects are presented during the assessment.

Given the above, it is recommended that all assessment protocols used in psychological expertise examinations in cases of interparental conflicts be comprehensive and thorough, involving the entire family system and the triangulation of multiple sources and methodologies, and be sufficiently flexible to adjust to each particular case. In addition to the procedures and techniques listed above (e.g., consultation of the case; informed consent; interviews; observation of interactions), there are several specific techniques that can equally assist in achieving this type of assessment. Thus, the international literature has shown a special consensus concerning the use of empirically validated instruments (e.g., the Achenbach System of Empirically Based Assessment - ASEBA; Achenbach \& Rescorla, 2004; Achenbach et al., 2014), in addition to the use of observations and semi-structured interviews with the child (e.g., Semi-Structured Clinical Interview for Children and Adolescents - SCICA) and the adults (individual and group), which make it possible to evaluate the dimensions cited above, among several other aspects. In addition, the use of inventories that evaluate beliefs, styles, and educational practices and the use of some psychological tests are also use-

adversarial expert assessments that would make it possible for the parties involved to present an expert assessment other than that conducted by an expert assigned by the court (Gomes de Sousa, 2011). However, the Portuguese Code of Criminal Procedure provides for a technical consultant whose duties are to inspect and counsel the party, attend the assessment with the possibility of intervening - article 155(2) - and be heard in a court hearing (article 350); however, participation in the preparation of the expert report is not included (article157). 
ful in evaluating personality dimensions (e.g., the Sixteen Personality Factor Questionnaire 16PF), psychopathological symptoms (e.g., the Brief Symptom Inventory - BSI), and the risk of violence (e.g., the Spousal Assault Risk Assessment Guide - SARA). These instruments should be used according to the complexity of the cases under analysis and should alternate with other suitable techniques. The core principle to be established in the assessment is the well-being and best interest of the child, and the expert assessment should be conducted based on the orientations explained above, in addition to internationally accepted orientations (American Psychological Association, 2009).

\section{Final Considerations}

Witnessing interparental conflicts is one of the most striking experiences for a child and has serious implications for the child's overall adjustment. These conflicts are experienced so intensely that some children develop maladaptive behaviors that may persist over the short, medium, and long terms. Several factors should be considered in the analysis of this impact, which may not be evident in certain cases, because the assessment must address the evident stressor (the interparental conflict) and other factors that are associated with the child, family, or context. Not only may some of these factors increase the risk of a negative impact but also some may function as protective mediators of a less negative impact.

The expert who conducts the forensic psychological assessment in cases of interparental conflicts should gather a comprehensive analysis of these theoretical aspects and should demonstrate technical and scientific competence to address the objectives of the consultation that he/ she was requested to conduct. There are several obstacles and complexities to be handled within the scope of expert assessments in cases of families characterized by conflictual experiences and in which children are often present. Although there is no universal definition of appropriate parenting style, this is one of the aspects that should be addressed when expert assessments are conducted. Other aspects such as the dynam- ics, relationships, bonds, and expressed preferences and dislikes are part of the dimensions to be analyzed for which there simple and complex underlying processes that must be further are evaluated. The forensic psychological assessment should assist the court in serving the best interest of the child.

\section{References}

Achenbach, T. M., \& Rescorla, L. A. (2004). The Achenbach System of Empirically Based Assessment (ASEBA). In M. E. Maruish (Eds.), The use of psychological testing for treatment planning and outcomes assessment. Vol. 2: Instruments for Children and Adolescents ( $3^{\text {rd }}$ ed., pp. 179-213). Mahwah, NJ: Lawrence Erlbaum Associates.

Achenbach, T., Rescorla, L. A., Dias, P., Ramalho, V., Lima, V., Machado, B., \& Gonçalves, M. (2014). Manual do Sistema de Avaliação Empiricamente Validado (ASEBA): Um sistema integrado de avaliação com múltiplos informadores. Manual do periodo pré-escolar e do periodo escolar. Braga, Portugal: Psiquilibrios.

Agulhas, R. (2014). A avaliação das competências parentais e a audição de crianças em contexto judiciário. In Centro de Estudos Judiciários (Ed.), A tutela civel do superior interesse da criança. Vol. III (pp. 224-229) Lisboa: Centro de Estudos Judiciários. Retrieved from http://www.cej. mj.pt/cej/recursos/ebooks/familia/Tutela_Civel_Superior_Interesse_Crianca_TomoIII.pdf

Agulhas, R., \& Anciães, A. (2014). Casos práticos em Psicologia Forense. Enquadramento legal e avaliação pericial. Lisboa: Edições Sílabo.

Almeida, T., \& Sani, A. (2014). Violência entre pais: Efeitos e transmissão entre gerações. In F. Almeida \& M. Paulino (Eds.), Psicologia, Justiça e Ciências Forenses (pp. 135-150). Lisboa: Pactor.

American Psychological Association. (2009). Guidelines for child custody evaluations in family legal proceedings. Washington, DC: Author. Retrieved from https://www.apa.org/practice/ guidelines/child-custody.pdf

Bevan, E., \& Higgins, D. J. (2002). Is domestic violence learned? The contribution of five forms of child maltreatment to men's violence and adjustment. Journal of Family Violence, 17(3), 223-245. 
Black, D. S., Sussman, S., \& Unger, J. B. (2010). A further look at the intergenerational transmission of violence: Witnessing interparental violence in emerging adulthood. Journal of Interpersonal Violence, 25(6), 1022-1042.

Bowen, E. (2015). The impact of intimate partner violence on preschool children's peer problems: An analysis of risk and protective factors. Child Abuse \& Neglect, 50, 141-150.

Camisasca, E., Miragoli, S., \& Di Blasio, P. (2016). Families with distinct levels of marital conflict and child adjustment: Which role for maternal and paternal stress? Journal of Child and Family Studies, 25(3), 733-745.

Costa, V. A., \& Sani, A. I. (2007). Sintomatologia de pós-stress traumático em crianças expostas a violência interparental: Do conflito ao ajustamento. Revista da Faculdade de Ciências da Saúde, Universidade Fernando Pessoa, 4, 282-290. Retrieved from http://bdigital.ufp.pt/ handle/10284/419.

Coutinho, M. J., \& Sani, A. I. (2008). Evidência empírica na abordagem sobre as consequências da exposição à violência interparental. Revista da Faculdade de Ciências da Saúde, Universidade Fernando Pessoa, 5, 284-293. Retrieved from https://bdigital.ufp.pt/dspace/handle/10284/970.

Cox, J., Paley, B., \& Harter, K. (2001). Interparental conflict and parent - Child relationships. In J. H. Grych \& F. D. Fincham (Eds.), Interparental conflict and child development (pp. 249-272). Cambridge, MA: Cambridge Press.

Cunningham, A., \& Baker, L. (2004). What about me! Seeking to understand the child's view of violence in the family. London: Centre for Children and Families in the Justice System.

Dankoski, M. E., Keiley, M. K., Thomas, V., Choice, P., Lloyd, S. A., \& Seery, B. L. (2006). Affect regulation and the cycle of violence against women: New directions for understanding the process. Journal of Family Violence, 21, $327-$ 339.

Dunn, J., \& Davies, L. (2001). Sibling relationships and interparental conflict. In J. H. Grych \& F. D. Fincham (Eds.), Interparental conflict and child development (pp. 273-290). Cambridge, MA: Cambridge Press.

English, J. D., Graham, J. C., Newton, R. R., Lewis, T. L., Thompson, R., Kotch, J. B., \& Weisbart, C. (2009). At-risk and maltreated children ex- posed to intimate partner aggression/violence What the conflict looks like and its relationship to child outcomes. Child Maltreatment, 14(2), 157-171.

Fialho, A. J. (2012). Guia prático do divórcio e responsabilidades parentais. Coleção Guias Práticos ( $2^{\text {nd }}$ ed.). Lisboa: Centro de Estudos Judiciários. Retrieved from http://www.cej.mj.pt/ cej/recursos/ebooks/familia/guia_pratico_divorcio_responsabilidades_parentais.pdf

Fergusson, D. M., Boden, J. M., \& Horwood, L. J. (2008). Developmental antecedents of interpartner violence in a New Zealand birth cohort. Journal of Family Violence, 23, 737-753.

Gomes de Sousa, J. H. (2011). A 'perícia' técnica ou científica revisitada numa visão prático-judicial. Julgar, 15, 27- 52.

Herrenhohl, T., Sousa, C, Tajima, E., Herrenhohl, R., $\&$ Moylan, C. (2008). Intersection of child abuse and children's exposure to domestic violence. Trauma, Violence \& Abuse, 9, 84-99.

Howell, K. H. (2011). Resilience and psychopathology in children exposed to family violence. $\mathrm{Ag}$ gression and Violent Behavior, 16, 562-569.

Hughes, H. M., Graham-Bermann, S. A., \& Gruber, G. (2001). Resilience in children exposed to domestic violence. In S. A. Graham-Bermann \& J. Edleson (Eds.), Domestic violence in the lives of children. The future of research, intervention and social policy (pp. 67-90). Washington, DC: American Psychological Association.

Huss, M. T. (2011). Psicologia Forense. Pesquisa, prática clínica e aplicações. Porto Alegre, RS: Artmed.

Laporte, L., Jiang, D., Pepler, D. J., \& Chamberland, C. (2011). The relationship between adolescents' experiences of family violence and dating violence. Youth and Society, 43, 3-27.

Levendosky, A. A., Bogat, G. A., \& Huth-Bocks, A. C. (2011). The influence of domestic violence on the development of the attachment relationship between mother and young child. Psychoanalytic Psychology, 28, 512-527.

Machado, M. L., \& Sani, A. (2014). Avaliação psicológica forense na regulação do exercício das responsabilidades parentais. Perceções dos juízes. In F. Almeida \& M. Paulino (Eds.), Psicologia, Justiça e Ciências Forenses (pp. 357-371). Lisboa: Pactor. 
Machado, M. L. \& Sani, A. (2015). A (síndroma de) alienação parental. Revista Digital Lusobrasileira de Alienação Parental, 7, 164-176. Retrieved from http://issuu.com/sandraines3/docs/revista aliena o_parental 7 .

Manning, L. G., Davies, P. T., \& Cicchetti, D. (2014). Interparental violence and childhood adjustment: How and why maternal sensitivity is a protective factor. Child Development, 85(6), 2263-2278.

Marasca, A. R., Colossi, P. M., \& Falcke, D. (2013). Violência conjugal e família de origem: Uma revisão sistemática da literatura de 2006 a 2011. Temas em Psicologia, 21(1), 221-243.

Molinari, F., \& Sani, A. I. (2015a). Mediação Familiar em contextos de alienação parental: Perspectiva para uma coparentalidade positiva. In C. P. Rosa \& L. M. B. Thomé (Eds.), Um presente para construir o futuro: Escritos sobre Família e Sucessões (pp. 184-209). Porto Alegre, RS: Instituto Brasileiro de Direito de Família Seção do Rio Grande do Sul.

Molinari, F., \& Sani, A. I. (2015b). Um olhar multidisciplinar sobre o fenômeno da Alienação Parental. In C. P. Rosa (Ed.), Família e sucessões: Novos temas e discussões (pp. 326-338). Porto Alegre, RS: RJR.

Molinari, F., \& Trindade, J. (2014). Reflexões sobre alienação parental e a escala de indicadores legais de alienação parental. In C. P. Rosa \& L. M. B. Thomé (Eds.), O Direito no lado esquerdo do peito: Ensaios sobre direito de família e sucessões (pp. 23-33). Porto Alegre, RS: Instituto Brasileiro de Direito de Família - Seção do Rio Grande do Sul.

Patias, N. D., Bossi, T. J., \& Dell'Aglio, D. D. (2014). Repercussões da exposição à violência conjugal nas características emocionais dos filhos: Revisão sistemática da literatura. Temas em Psicologia, 22(4), 901-915.

Peixoto, C., Ribeiro, C., \& Manita, C. (2007). Avaliação psicológica forense das capacidades parentais. Revista da SPTM, 11(2), 142-156.

Pereira, A., \& Matos, M. (2011). Avaliação psicológica das responsabilidades parentais nos casos de separação e divórcio. In M. Matos, R. A. Gonçalves, \& C. Machado (Eds.), Manual de Psicologia Forense: Contextos, práticas e desafios (pp. 311-347). Braga, Portugal: Psiquilíbrios.
Pereira, D., \& Alarcão, M. (2010). Avaliação da parentalidade no quadro da proteção à infância. Temas em Psicologia, 18(2), 499-517.

Pryor, J. E., \& Pattison, R. (2007). Adolescents' perceptions of parental conflict: The downside of silence. Journal of Family Studies, 13(1), 72-77.

Sani, A. I. (2004a). O discurso de crianças expostas à violência interparental - Estudo Qualitativo. Psychologica, 36, 109-130.

Sani, A. I. (2004b). Abordagens teóricas da violência interparental: Compreensão do ajustamento da criança ao conflito dos pais. Psicologia: Teoria, Investigação e Prática, 2, 153-177.

Sani, A. I. (2006). As variáveis mediadoras do impacto na criança da exposição à violência interparental. Psicologia: Teoria, Investigação e Prática, 11(2), 111-133.

Sani, A. I. (2007). Las consecuencias de la violencia interparental en la infancia. In R. Arce, F. Fariña, E. Alfaro, C. Civera, \& F. Tortosa (Eds.), Psicología Jurídica: violencia y victimas (pp. 13-21). Valencia, Spain: Sociedad Española de Psicología y Ley.

Sani, A. I. (2011). Crianças vitimas de violência: Representações e impacto do fenómeno. Porto, Portugal:Edições UniversidadeFernando Pessoa.

Sani, A., \& Almeida, T. (2011a). Violência interparental: A vitimação indirecta de crianças. In A. I. Sani (Ed.), Temas de Vitimologia: Realidades emergentes e respostas sociais (pp. 11-31) Coimbra, Portugal: Almedina.

Sani, A., \& Almeida, T. (2011b). Avaliação psicológica de crianças expostas à violência interparental. In M. Matos, R. A. Gonçalves, \& C. Machado (Eds.), Manual de Psicologia Forense: Contextos, práticas e desafios (pp. 159-173). Braga, Portugal: Psiquilibrios.

Simon, V. A., \& Furman, W. (2010). Interparental conflict and adolescents' romantic relationship conflict. Journal of Research on Adolescence, 20(1), 188-209. 